\title{
Effects of Spent Composts of Se-Enriched Mushrooms on Carcass Characteristics, Plasma GSH-Px Activity, and Se Deposition in Finishing Hanwoo Steers
}

\author{
S. H. Lee*, B. Y. Park** and W. Y. Kim*
}

Department of Animal Science, Korea National Agricultural College, RDA, Suwon, 445-893, Korea* National Livestock Research Institute, RDA, Suwon, 441-706, Korea**

셀레늄급원으로 셀레늄강화버섯 폐배지의 급여가 거세한우의 도체

$$
\begin{gathered}
\text { 특성, 혈중 GSH-Px활성 및 조직내 셀레늄축적에 미치는 영향 } \\
\text { 이성훈*· 박범영**·김완영* } \\
\text { 한국농업전문학교 축산학과*, 축산연구소** }
\end{gathered}
$$

적 요

본 연구는 셀레늄급원으로 셀레늄강화버섯 폐배지(Se-SMC)를 거세한우에 급여하였을 때, 도체특 성, 혈중 GSH-Px활성 및 조직내 셀레늄축적에 미치는 영향을 조사하기 위하여 실시하였다.

본 실험에 사용된 셀레늄급원은 유기셀레늄강화버섯을 생산한 후 폐기되는 버섯폐배지를 활용하 였으며, 일반폐배지(SMC)를 조합하여 실험사료의 셀레늄 농도를 0.1, 0.3, 0.6, $0.9 \mathrm{ppm}$ (건물기준)의 4 처리구로 설정하였다. 실험동물은 비육후기 거세한우 20 두(평균체중 $613 \mathrm{~kg}, 20 ~ 24$ 개월령)를 공 시하여, 처리구간 5 두씩 배치하여 실험사료를 12 주간 급여하였다. 실험기간 중 채혈하여 혈중 셀레 늄농도와 혈장내 GSH-Px활성을 측정하였고, 근육(등심, 후지)과 간내 셀레늄함량과 도체특성을 측정 하기위해 시험 후 도축하였다. Se-SMC의 보충으로 증가된 셀레늄수준은 건물섭취량과 증체량에 영 향을 미치지 않았고, 높은 농도의 처리군에서 중독증상은 발견되지 않았다.

도체특성 또한 처리구별 유의적인 차이를 나타내지 않았다. 혈중 셀레늄농도와 혈장내 GSH-Px활 성은 Se-SMC급여수준이 증가함에 따라 직선적으로 유의하게 증가하였다 $(\mathrm{P}<0.01)$. 근육과 간내 셀레 늄함량은 후지 및 간에서 사료중 셀레늄함량이 증가함에 따라 각각 건물 $\mathrm{g}$ 당 $0.27,0.37,0.40,0.46$ $\mu \mathrm{g}$ 및 $0.79,1.40,2.39,3.10 \mu \mathrm{g}$ 를 나타내어 유의하게 증가하였다( $\mathrm{P}<0.05)$. 하지만, 등심내 셀레늄함량 은 처리구간 유의적인 차이를 보이지 않았다.

이상과 같이 Se-SMC에 존재하는 셀레늄은 비육후기 거세한우에서 혈중 셀레늄농도와 GSH-Px활 성을 유의하게 증가시킬 뿐만 아니라, 조직내 셀레늄함량을 증가시켜 저렴한 생산비로 셀레늄강화 쇠고기의 생산이 가능할 것으로 판단된다.

(주요어 : 셀레늄, 버섯폐배지, 도체특성, GSH-Px활성, 조직내 셀레늄축적, 거세한우)

\footnotetext{
Corresponding author : W. Y. Kim, Department of Animal Science, Korea National Agricultural College, Suwon, 445-893, Korea, Tel: +82-31-229-5032, Fax: +82-31-229-5055, E-mail: wykim@ rda.go.kr
} 


\section{INTRODUCTION}

It has been well documented that selenium (Se) plays an important role in the cellular antioxidant defense system as an integral element of glutathione peroxidase (Rotruck et al., 1973). More recently, concerns for Se have been increased due to various health benefits including anticarcinogenic properties (Clark et al., 1996; Rayman, 2000). Holben and Smith (1999) also demonstrated that Se has many physiological functions as a component of selenoproteins responsible for a variety of Sedependent diseases. Glutathione peroxidase (GSH$\mathrm{Px}$ ), one of selenoproteins, degrades free radicals including hydrogen peroxides to harmless water or alcohol, in coordination with catalase, within the cell (Tapiero et al. 2003). For these reasons, many animal nutritionists have made attempts to accumulate Se into animal products such as meat (Mahan and Parrett, 1996), milk (Ortman and Pehrson, 1999) and egg (Surai, 2000) by supplementing Se in the feed. Ku et al. (1973) reported that organic Se was more effective in intestinal absorption and the retention of the animal tissues in comparison with inorganic Se such as sodium selenite and selenate. Se-yeasts (Sel-Plex, Alltech, Inc.) are generally utilized as organic Se source, however, they are relatively expensive.

Meanwhile, by utilizing the Se-accumulating property of mushroom (Van Elteren et al., 1998), Se-enriched mushroom and spent mushroom composts (SMC) can be produced when inorganic Se such as sodium selenite was added to mushroom composts (MC) and it was proven that spent mushroom composts (Se-SMC) contain considerable amount of Se mainly as the organic form (Lee, 2004). Thus, we hypothesized that if SMC is fed to beef cattle for Se source as well as feed source, it can not only produce Se- fortified beef but also reduce feed cost. For this reason, effects of Se from SMC of Se-enriched mushrooms on carcass characteristics, plasma GSH-Px activity, and Se deposition in finishing Hanwoo (Bos taurus coreanae) beef steers were investigated.

\section{MATERIALS AND METHODS}

\section{Preparation of spent mushroom com- posts and experimental design}

SMC used in this experiment was obtained from two different mushroom farms where cultivated Se-enriched and normal mushrooms with the same species (Flammulina velutipes) and growth condition. The production of Se-enriched mushroom is achieved by supplementing inorganic Se as sodium selenite (2 mg Se per $\mathrm{kg}$ composts) in the composts and normal mushroom is produced by the conventional method without the supplement of sodium selenite. After about 60-d period of mushroom culture, each mushroom is harvested and each SMC is stacked up outside, separately. Both the SMCs were transported into the Hanwoo cattle farm located at Chonnam province of Korea to be utilized as a feed ingredient of experimental diets. The chemical compositions of each SMC from Se-enriched and normal mushrooms are presented in Table 1.

Steers were assigned randomly to one of four treatments ( $\mathrm{n}=5$ per treatment): 0.1 (control), $0.3,0.6$, and $0.9 \mathrm{ppm}$ Se diets were determined by supplementing Se-SMC and/or SMC. Thus, a total of 20 finishing Hanwoo steers (average $\mathrm{BW}=613 \mathrm{~kg}$, average age $=20$ to $24 \mathrm{mo}$ ), as similar as possible in age and body weight, were allotted to treatments in four groups of five steers per pen. 
Table 1. Chemical compositions of each SMC from Se-enriched and common mushrooms

\begin{tabular}{|c|c|c|c|c|c|c|c|}
\hline Item & $\begin{array}{c}\text { Dry } \\
\text { matter, g }\end{array}$ & $\begin{array}{c}\text { Crude } \\
\text { protein, g }\end{array}$ & $A D F, g^{1)}$ & NDF, $g^{2)}$ & $\begin{array}{c}\text { Ether } \\
\text { extract, g }\end{array}$ & $\begin{array}{l}\text { Crude } \\
\text { ash, g }\end{array}$ & Se, mg \\
\hline & \multicolumn{7}{|c|}{ 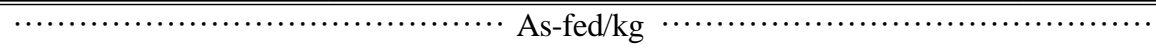 } \\
\hline Se-SMC ${ }^{3)}$ & 492.9 & 42.4 & 284.1 & 393.3 & 17.7 & 34.1 & 2.48 \\
\hline $\mathrm{SMC}^{4)}$ & 490.1 & 41.6 & 285.4 & 401.4 & 16.5 & 34.7 & 0.08 \\
\hline
\end{tabular}

1) Acid detergent fiber; ${ }^{2)}$ neutral detergent fiber; ${ }^{3)}$ spent mushroom composts from Se-enriched mushrooms;

4) spent mushroom composts from normal mushrooms.

2. Experimental diets, feeding, and management

Ingredients and chemical compositions of the experimental diets are presented in Table 2. Experimental diets were formulated to combine Se-SMC with SMC in order to adjust the levels of Se in the diets. Se contents in the treatment diets were within the range of expected concentrations, and also CP and TDN contents (on the dry matter basis) were similar among treatments showing approximately 11 to $12 \%$ and 74 to $75 \%$, respectively in experimental diets (Table 2). Thus, diets were isocaloric and isonitrogenous among treatments. The nutritional contents of experimental diets were determined on the basis of the official Korean feeding standard for Hanwoo beef cattle (MAF and NLRI, 2002). Due to the high concentration of moisture for SMC, the diets were formulated on the cycle of 2-wk period to prevent the unfavorable fermentation. The experimental diets were stored in the polyethylene vinyl envelope with $0.7 \times 1.5 \mathrm{~m}$ size in order to keep anaerobic condition until fed to animals. Diets were analyzed for Se content to make sure that they contain the appropriate treatment Se levels after formulated and packed.

All steers were conformed to the experimental environment and experimental diets for 2-wk period in which cows were gradually switched from a conventional diet to the experimental diet, and the main feeding trial was subsequently lasted for $12 \mathrm{wk}$. Treatment diets were provided for ad libitum intake twice daily at 0700 and 1900, and water was allowed to be accessible freely through the automatic water provider.

The water contained undetectable concentration of Se $(<2 \mathrm{ng} / \mathrm{mL})$. Daily dry matter intakes were recorded by the difference between the supply and ort amounts, and initial and final body weights for all animals were measured to observe body weight gain on the basis of daily and entire period. At the end of the experimental period, all animals were slaughtered at the slaughterhouse (National Agricultural Cooperative Federation, Chonnam, Korea) for collection of tissues from loin (m. longissimus thoracis) and hind leg (m. triceps surae) as skeletal muscles, and liver as a high metabolic organ for Se.

\section{Sample collections and analytical methods}

Each treatment diet was collected after manufactured and analyzed for nutritional components according to AOAC (1995). ADF and NDF were determined according to method described by Van Soest et al. (1991). Blood samples were collected from the jugular vein into 10-mL heparinized tubes (Vacutainer tube, Becton-Dickinson, Inc., NJ, USA) at 2, 4, 8 and 12 wk after feeding for measurements of whole 
Table 2. Ingredient and composition of experimental diets

\begin{tabular}{|c|c|c|c|c|}
\hline \multirow{2}{*}{ Item } & \multicolumn{4}{|c|}{ Treatments, ppm Se } \\
\hline & 0.1 & 0.3 & 0.6 & 0.9 \\
\hline \multicolumn{5}{|l|}{ Ingredient (\%, as-fed) } \\
\hline Se-SMC ${ }^{1)}$ & - & 5.85 & 15.20 & 24.60 \\
\hline $\mathrm{SMC}^{1)}$ & 24.60 & 18.75 & 9.40 & - \\
\hline Corn, grain & 55.54 & 55.54 & 55.54 & 55.54 \\
\hline Barley, grain & 5.40 & 5.40 & 5.40 & 5.40 \\
\hline Corn gluten meal & 1.89 & 1.89 & 1.89 & 1.89 \\
\hline Tall fescue, straw & 4.74 & 4.74 & 4.74 & 4.74 \\
\hline Barley bran & 1.89 & 1.89 & 1.89 & 1.89 \\
\hline Molasses, sugarcane & 5.85 & 5.85 & 5.85 & 5.85 \\
\hline Vitamin/mineral mix $^{2)}$ & 0.09 & 0.09 & 0.09 & 0.09 \\
\hline \multicolumn{5}{|c|}{ Chemical composition (dry matter basis) } \\
\hline Dry matter (\%) & 75.69 & 75.42 & 75.74 & 75.51 \\
\hline Crude protein (\%) & 11.66 & 11.82 & 11.49 & 11.19 \\
\hline Acid detergent fiber (\%) & 12.05 & 12.15 & 12.18 & 12.12 \\
\hline Neutral detergent fiber (\%) & 17.64 & 17.74 & 17.70 & 17.55 \\
\hline Ether extract (\%) & 2.46 & 2.02 & 2.85 & 2.92 \\
\hline Crude ash (\%) & 2.28 & 2.19 & 2.32 & 2.33 \\
\hline Calcium (\%) & 0.84 & 0.87 & 0.85 & 0.83 \\
\hline Phosphorus (\%) & 0.28 & 0.31 & 0.30 & 0.29 \\
\hline Selenium (mg/kg) & 0.083 & 0.299 & 0.623 & 0.897 \\
\hline $\mathrm{TDN}^{3)}(\%)$ & 74.27 & 74.90 & 74.95 & 74.55 \\
\hline Se intake, $\mu \mathrm{g} \cdot \mathrm{kg} \mathrm{BW}{ }^{-} \cdot \mathrm{d}^{-}$ & 1.77 & 6.31 & 13.19 & 18.91 \\
\hline
\end{tabular}

\footnotetext{
${ }^{1)}$ See Table $1 ;{ }^{2)}$ consisted of Ca 15\%, P 6.8\%, Mg 7.0\%, Na 7.8\%, Zn 5,000 mg/kg, Mn 4,000 mg/kg, Cu 500 mg/kg, I $300 \mathrm{mg} / \mathrm{kg}$, Co $20 \mathrm{mg} / \mathrm{kg}$, Se $0 \mathrm{mg} / \mathrm{kg}$, vitamin A 400,000 IU/kg, vitamin $\mathrm{D}_{3}$ 75,000 IU/kg, and vitamin E $500 \mathrm{mg} / \mathrm{kg}$;

${ }^{3)}$ TDN value was calculated according to the equation of NRC (1996).
}

blood Se concentration and GSH-Px activity in plasma. Blood samples for whole blood Se analyses were frozen at $-75^{\circ} \mathrm{C}$ ind freeze-dried. Blood samples for GSH-Px activity were immediately centrifuged $(1,500 \times \mathrm{g}$ for $15 \mathrm{~min})$ to obtain plasma, which was stored at $-75^{\circ} \mathrm{C}$ until analysis. Loin, hind leg and liver (each $\sim 1$ $\mathrm{kg} / \mathrm{cut}$ ) taken from slaughtered animals were thoroughly minced, freeze-dried, and kept at $-75^{\circ} \mathrm{C}$ until analysis. With loin and hind leg tissues, subcutaneous fats were removed to analyze total Se content. Se contents were determined by spectrophotometric assay accord- ing to AOAC (1995) after sample ignition using the oxygen combustion flask method described by Stijve (1977).

Carcass characteristics (backfat thickness, ribeye area, marbling score, meat color, fat color, texture, yield grade, and quality grade) were assessed at 24 hours postmortem by carcass grader of National Agricultural Cooperative Federation in Korea. GSH-Px activity in plasma was assayed by the coupled enzymatic method of Lawrence and Burk (1976) with hydrogen peroxide and cumene hydroperoxide as the substrate. 


\section{Statistical analysis}

Statistical analysis for all dependent variables was performed as a completely randomized design using the general linear model (GLM procedures) of SAS program (SAS Inst., Cary, NC, 2000). Dependent variables were performances (DMI and BW), carcass characteristics, Se concentrations in whole blood, plasma GSH-Px activities and Se contents in tissues. The model included treatment (Se level in the diet, $\mathrm{df}=3)$ and steers within treatment $(\mathrm{df}=4)$. Steers within treatment were used as error terms to test effects of treatments. Significant differences among treatments were determined by Duncan's multiple range test at a level of $\mathrm{P}<$ 0.05 (Steel and Torrie, 1980).

\section{RESULTS AND DISCUSSION}

\section{Performances and carcass characteristics}

Increased dietary levels of Se by incorporating Se-SMC into the treatment diets did not affect DM intakes for Hanwoo steers throughout the trial (Table 3). The present result agreed with the data of Rock et al. (2001) and Gunter et al. (2003), who reported that Se level increased by organic (0.3 and $26 \mathrm{ppm}$, respectively) or inorganic (0.3 and $26 \mathrm{ppm}$, respectively) Se supplementation in the diets of gestational ewes and beef cows, respectively, did not affect feed intakes.

The feeding regimen for Se in the present study did not result in any sign of selenosis, such as hair loss, separation of the hoof, respiratory failure and so on, as described in NRC (1996). Even though it has been known to be toxic in dietary Se level from 5 to $20 \mathrm{ppm}$ in swine, resulting in decreased ADG and feed intake (Kim and Mahan, 2001), toxic level of dietary Se for cattle has not been well defined. Hintze et al. (2002) reported that a ration containing more than $10 \mathrm{ppm}$ of Se for beef steers did not influence feed intake and showed no any toxic symptoms. One can assume that ruminants might be more tolerable for Se toxicity than monogastrics. Therefore, the highest level of Se $(0.9 \mathrm{ppm})$ of the present study was very safe in terms of steer heath.

In addition, total BW gain and ADG of Hanwoo steers during the entire period were not affected by increasing levels of Se (Table 3). Numerous studies were investigated to determine effects of dietary Se sources or levels on the Se transfer to tissue for fortification and prevention

Table 3. Effects of increasing levels of Se from Se-SMC on performances of Hanwoo steers

\begin{tabular}{|c|c|c|c|c|c|c|}
\hline \multirow{2}{*}{ Item } & \multicolumn{4}{|c|}{ Treatments, ppm Se } & \multirow{2}{*}{ SEM $^{1)}$} & \multirow{2}{*}{$P<^{2)}$} \\
\hline & 0.1 & 0.3 & 0.6 & 0.9 & & \\
\hline Period of feeding & \multicolumn{6}{|c|}{$\ldots \ldots \ldots \cdots \cdots$ Dry matter intake $(\mathrm{kg} / \mathrm{steer} / \mathrm{d}) \cdots \cdots \cdots \cdots$} \\
\hline 1 to $30 \mathrm{~d}$ & 9.05 & 9.04 & 9.12 & 9.08 & 1.27 & 0.9994 \\
\hline 31 to $60 \mathrm{~d}$ & 9.38 & 9.55 & 9.47 & 9.33 & 1.29 & 0.9662 \\
\hline 61 to $90 \mathrm{~d}$ & 9.53 & 9.39 & 9.54 & 9.58 & 1.31 & 0.9726 \\
\hline Overall & 9.37 & 9.37 & 9.44 & 9.37 & 1.28 & 0.9942 \\
\hline \multicolumn{7}{|c|}{$\ldots \ldots \ldots \ldots \ldots \ldots$ Body weight gain $\ldots \ldots \ldots \ldots \ldots \ldots$} \\
\hline Total BW gain, kg & 65.78 & 66.45 & 65.57 & 66.32 & 9.37 & 0.9988 \\
\hline $\mathrm{ADG}^{3)}, \mathrm{g}$ & 730.87 & 738.36 & 728.50 & 736.83 & 104.14 & 0.9988 \\
\hline
\end{tabular}

${ }^{1)}$ Standard error of the mean; ${ }^{2)} \mathrm{P}$-value is significantly different among treatments at a level of $<0.05$;

3) average daily gain. 
of Se deficiency in the animals. Of these studies, Lawler et al. (2004) reported that when beef steers were provided diets with 0.38 or 2.8 ppm of Se using the high-Se wheat and sodium selenate, the high levels of dietary Se did not affect ADG, feed efficiency, and DMI. Likewise, data from Rock et al. (2001) showed that BW of groups supplemented with sodium selenite (0.3 ppm) or Se-enriched yeast (0.3 ppm) did not differ compared with non-supplemented ewes and was unaffected by source and level of Se supplementation. These studies were in accordance with our result, showing that excess level of dietary Se $(0.9$ ppm) was not negatively limited in performances of finishing beef steers.

All parameters included in the carcass characteristics were not influenced by Se-SMC and dietary Se levels (Table 4). These responses were consistent with the results of Mahan et al. (1999) and Lawler et al. (2004) who indicated that the major carcass characteristics were not influenced by the dietary Se levels or sources (inorganic vs. organic Se). However, Se effects on meat color, texture, and storage are needed to be further studied, since it is well known that Se has a powerful antioxidant action and water-holding capacity (DeVore and Greene, 1982; Mahan et al., 1999).

\section{Blood measurements}

Se concentrations in whole blood of Hanwoo steers were significantly increased with enhancing levels of Se in diets $(\mathrm{P}<0.01$; Fig. 1). The significant differences of whole blood Se concentrations across treatments were clearly noted with increasing levels of dietary Se. The effect by increasing levels of Se from SMC was accomplished within $2 \mathrm{wk}$ and subsequently reached a plateau after $4 \mathrm{wk}$. These results were similar to those from Ortman and Pehrson (1999), who reported that the supplementation of different Se sources in the diet of dairy cows elevated the whole blood Se levels within $2 \mathrm{wk}$, in which Se-yeast consisting of mainly selenomethionine as the organic Se form showed a much higher level for whole blood Se than the inorganic Se such as sodium selenite and selenate. Increased Se levels by the organic Se (Se-yeast) in the above study were similar to those of our results. Thus, one could postulate that Se present in Se-SMC was excellent in the

Table 4. Effects of increasing levels of Se from Se-SMC on carcass characteristics of Hanwoo steers

\begin{tabular}{|c|c|c|c|c|c|c|}
\hline \multirow{2}{*}{ Item } & \multicolumn{4}{|c|}{ Treatments, ppm Se } & \multirow{2}{*}{$\mathrm{SEM}^{1)}$} & \multirow{2}{*}{$P<<^{2)}$} \\
\hline & 0.1 & 0.3 & 0.6 & 0.9 & & \\
\hline Dressing (\%) & 59.83 & 58.99 & 58.56 & 59.16 & 1.48 & 0.6053 \\
\hline Backfat thickness (mm) & 9.80 & 10.60 & 9.20 & 10.40 & 4.18 & 0.9505 \\
\hline Ribeye area $\left(\mathrm{cm}^{2}\right)$ & 86.80 & 76.00 & 82.60 & 81.20 & 7.89 & 0.2295 \\
\hline Marbling score ${ }^{3)}$ & 4.80 & 4.20 & 4.20 & 4.40 & 0.52 & 0.6213 \\
\hline Meat color ${ }^{4)}$ & 4.80 & 4.80 & 4.60 & 5.00 & 0.65 & 0.8152 \\
\hline Fat color ${ }^{5)}$ & 2.80 & 3.40 & 3.20 & 3.20 & 0.59 & 0.4606 \\
\hline Yield grade ${ }^{6)}$ & 1.60 & 2.00 & 1.40 & 1.60 & 0.58 & 0.4507 \\
\hline Quality grade ${ }^{7)}$ & 1.80 & 2.20 & 1.00 & 1.60 & 0.65 & 0.5254 \\
\hline
\end{tabular}

${ }^{1)}$ Standard error of the mean; ${ }^{2)} \mathrm{P}$-value is significantly different among treatments at a level of $<0.05 ;{ }^{3)} 1=$ least small and $7=$ most abundant; ${ }^{4)} 1=$ brightest and $7=$ thickest; $^{5)} 1=$ white and $7=$ brown; ${ }^{6)} \mathrm{A}=1, \mathrm{~B}=2$ and $\mathrm{C}=3 ;{ }^{7)}$ prime $^{+}$ grade $=0$, prime grade $=1$, 2nd grade $=2$ and 3 rd grade $=3$. 


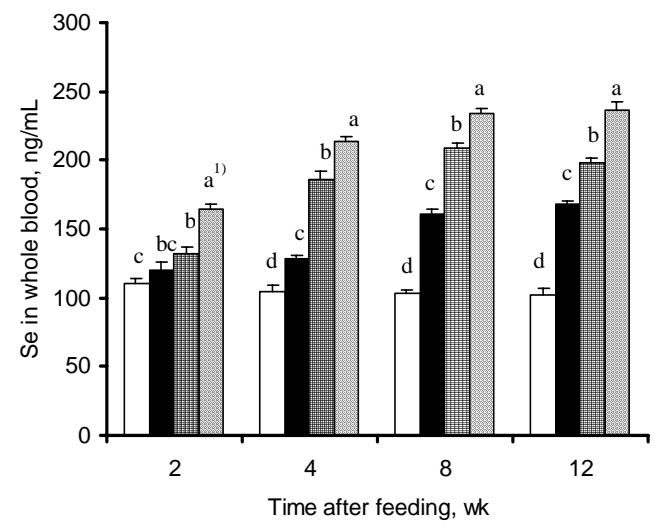

Fig. 1. Effects of increasing levels of Se supplementation on whole blood Se concentrations in Hanwoo steers. Legend: $0.1 \mathrm{ppm}$ of Se (open bar), $0.3 \mathrm{ppm}$ of Se (solid bar), $0.6 \mathrm{ppm}$ of Se (crosshatched bar), and 0.9 ppm of Se (diagonal bar).

1) a,b,c,d Within each feeding time, bars bearing different letters are significantly different $(\mathrm{P}<0.05)$; Vertical bars represent the standard error of the mean.

intestinal absorption and the main chemical form of Se present in Se-SMC would be likely to be molecular form of Se organically bound to the mycelium protein.

In many cases, the bioavailability of dietary Se for ruminants varies with the chemical form (Ortman and Pehrson, 1999; Gunter et al., 2003; Lawler et al., 2004), and forage to concentrate ratio of the diet (Koenig et al., 1997). In ruminants, organically bound $\mathrm{Se}$ in the diet is known to be more effective in the intestinal absorption and Se accumulation in tissues than inorganic Se sources with excretory pathway into feces via their formation of insoluble selenide in the rumen (Peterson and Spedding, 1963; Wright and Bell, 1966). Furthermore, Lee (2004) reported that Se present in Se-SMC from Se-enriched mushrooms used in this experiment was estimated by approximately $70 \%$ as the portion of organic Se built, possibly, by the mycelium. Stefánka et al. (2001) also demonstrated that inorganic Se added to mushroom compost was, after mushroom cultivation, converted to organic Se in edible mushrooms to some extent and their predominate form of Se was mostly selenocystine. However, Se distribution among different molecular forms for mushroom species and its SMC used in this experiment has to be further elucidated.

Meanwhile, even though glutathione peroxidase (GSH-Px) activities in plasma were less altered compared with whole blood Se concentrations due to the supplementation of Se-SMC, GSH-Px activities for groups supplemented with Se-SMC were generally higher than those of unsupplemented group as the control $(\mathrm{P}<0.01$; Table 5$)$. Significant differences among treatments began to be detected within $2 \mathrm{wk}$. After the supplementation period of $4 \mathrm{wk}$, steers fed diet containing $0.3 \mathrm{ppm}$ Se showed slightly higher GSH-Px activities compared to those of steers receiving no Se-SMC, but did not significantly differ. On the other hand, GSH-Px activities from 0.6 and $0.9 \mathrm{ppm}$ Se groups were much higher than those from 0.1 and $0.3 \mathrm{ppm}$ Se groups $(\mathrm{P}<0.05)$, but significant difference for GSH-Px activity was not observed between 0.6 and $0.9 \mathrm{ppm}$ treatments. Overall, whole pattern for GSH-Px moved upward as dietary Se levels increased, indicating that plasma GSH-Px activities were controlled by dietary Se content.

GSH-Px activities, a physiologically functional form of Se, have been proposed as the best estimate of Se status for human or animal (Stevens et al. 1985; Smith et al., 1988). Gunter et al. (2003) reported that supplementation of Se-enriched yeast or sodium selenite showed a higher GSH-Px activity in cows than cows with no Se supplementation. Similarly, Hintze et al. (2002) fed beef steers with a different background (seleniferous or nonseleniferous areas) either 11.9 or $0.62 \mathrm{mg}$ of $\mathrm{Se} / \mathrm{kg}$ of diet as 
high-Se hay and wheat mix, and they found that the increased GSH-Px activity was shown in the steers fed high-Se diet throughout the feeding trial, regardless of background. Proportional increases for GSH-Px activities observed in our experiments, therefore, seem to be closely related with the increased blood Se concentration by supplementing Se-SMC containing a high proportion of organic Se.

Meanwhile, the possible reason that no significant difference for the activity of GSH-Px between $0.1 \mathrm{ppm}$ and $0.3 \mathrm{ppm}$ after 4 wk was observed seems to be marginal blood Se concentration to express adequate activity of GSH-Px. As shown in Fig. 1, the whole blood Se concentrations for 0.6 and $0.9 \mathrm{ppm}$ of Se treatments started from $4 \mathrm{wk}$ were maintained more than $180 \mathrm{ng} / \mathrm{mL}$ that is known as adequate level (160 to $1,200 \mathrm{ng} / \mathrm{mL}$ ) for optimal GSH-Px activity and immune function(Puls, 1989), whereas blood Se concentrations in less than 0.3 ppm of Se treatments showed marginal levels (60 to $150 \mathrm{ng}$ Se/mL; Puls, 1989). Thus, it is considered that marginal points of blood Se concentration in our study acted as a limiting factor for the expression of adequate GSH-Px activity. However, in an investigation with swine by Mahan et al. (1999), a narrow range of Se concentrations with $0.05,0.1,0.2$ or $0.3 \mathrm{ppm}$ in the diet even increased quadratically GSH-Px activity compared with basal diet over a whole period. But one cannot rule out the possibility that such a result might be due to species specificity between ruminants and monogastrics.

Even though we could not show increases of GSH-Px activities at a low Se level (0.1 vs. 0.3 ppm), possibly due to low Se level in plasma and/or species specificity, we clearly showed that GSH-Px activities at higher levels of Se (0.6 and $0.9 \mathrm{ppm}$ ) were increased, resulting in beneficial effects on animal health.

\section{Se deposition in tissues}

As dietary Se levels increased, Se contents in hind leg and liver, except for loin, linearly ( $\mathrm{P}<$ 0.05) increased (Table 6). In contrast, although Se content in the loin was tended to increase for Se-SMC groups compared with steers supplemented with normal SMC alone, the effect of Se deposition by dietary Se levels was not statistically different. This result seems to be driven by marbling unevenly distributed in the loin, which leads to the dilution of Se bound to muscular protein. The evaluation of Se deposition based on loin, therefore, may be interfered

Table 5. Effect of increasing levels of Se supplementation on GSH-Px activities in plasma of Hanwoo steers

\begin{tabular}{|c|c|c|c|c|c|c|}
\hline \multirow{2}{*}{ Item } & \multicolumn{4}{|c|}{ Treatments, ppm Se } & \multirow{2}{*}{$\mathrm{SEM}^{1)}$} & \multirow{2}{*}{$P<^{2)}$} \\
\hline & 0.1 & 0.3 & 0.6 & 0.9 & & \\
\hline \multicolumn{7}{|c|}{ Supplementation period (wk) } \\
\hline 2 & $0.527^{(4)}$ & $0.658^{\mathrm{b}}$ & $0.931^{\mathrm{a}}$ & $0.939^{\mathrm{a}}$ & 0.0587 & $<0.0001$ \\
\hline 4 & $0.734^{\mathrm{b}}$ & $0.772^{\mathrm{b}}$ & $1.045^{\mathrm{a}}$ & $1.165^{\mathrm{a}}$ & 0.1027 & 0.0022 \\
\hline 8 & $0.697^{\mathrm{b}}$ & $0.740^{\mathrm{b}}$ & $1.060^{\mathrm{a}}$ & $1.168^{\mathrm{a}}$ & 0.0965 & 0.0007 \\
\hline 12 & $0.622^{\mathrm{b}}$ & $0.670^{\mathrm{b}}$ & $1.364^{\mathrm{a}}$ & $1.457^{\mathrm{a}}$ & 0.1318 & 0.0007 \\
\hline
\end{tabular}

${ }^{1)}$ Standard error of the mean; ${ }^{2)} \mathrm{P}$-value is significantly different among treatments at a level of $<0.05 ;{ }^{3)}$ One unit of GSH-Px activity equals $1 \mu \mathrm{mol}$ of NADPH oxidized per $\mathrm{min} / \mathrm{mL}$ of plasma; ${ }^{4) a, b, c}$ Means in a row with different superscripts are significantly different $(\mathrm{P}<0.05)$. 
Table 6. Effects of increasing level of Se from Se-SMC on Se contents in muscular and hepatic tissues

\begin{tabular}{|c|c|c|c|c|c|c|}
\hline \multirow{2}{*}{ Item } & \multicolumn{4}{|c|}{ Treatments, ppm Se } & \multirow{2}{*}{$\mathrm{SEM}^{1)}$} & \multirow{2}{*}{$P<^{2)}$} \\
\hline & 0.1 & 0.3 & 0.6 & 0.9 & & \\
\hline \multicolumn{7}{|c|}{$\ldots \ldots \ldots \cdots \cdots$ Tissue Se, $\mu \mathrm{g} / \mathrm{g}$ of dry weight $\ldots \ldots \ldots \ldots \ldots$} \\
\hline Loin & 0.314 & 0.410 & 0.367 & 0.393 & 0.0436 & 0.1113 \\
\hline Hind leg & $0.273^{\mathrm{b} 3)}$ & $0.368^{\mathrm{ab}}$ & $0.398^{\mathrm{a}}$ & $0.457^{\mathrm{a}}$ & 0.0526 & 0.0159 \\
\hline Liver & $0.789^{c}$ & $1.401^{\mathrm{bc}}$ & $2.392^{\mathrm{ab}}$ & $3.096^{\mathrm{a}}$ & 0.5590 & 0.0483 \\
\hline
\end{tabular}

by adipose tissue. As shown in our result, it may be more desirable to evaluate based on hind leg, which is relatively marbling-free fraction, because dietary Se sources is nonspecifically incorporated into protein fraction of body (McConnell and Hoffman, 1972). Se contents in hind leg and liver were the highest in the $0.9 \mathrm{ppm}$ Se diet, followed by those in 0.6, 0.3 , and $0.1 \mathrm{ppm}$ Se treatment $(\mathrm{P}<0.05)$. Our results showed that Se deposition in the tissue increased with supplementing Se as the form of Se-SMC.

Se concenation in the tissue is affected by the dietary concentration and chemical form of Se (Kim and Mahan, 2001; Hintze et al., 2002). It is also known that Se from organic sources is more efficiently incorporated into tissue than inorganic sources of Se (Van Ryssen et al., 1989; Lawler et al., 2004).

Hintze et al. (2001) reported that in ruminants, skeletal muscle Se had a stronger association $(r=$ 0.66) with whole blood Se among other parameters, thus Se concentration of whole blood was the best predictor for that of skeletal muscle. Similarly, our results showed that muscular Se concentration was proportionally increased with enhancing Se level in the diet as the form of Se-SMC. Many studies have reported that the feeding of organic sources such as Se-enriched yeasts and some forages or grains from seleniferous regions during the defined period enabled animals to increase blood Se concentration and to accumulate Se in their tissues (Van Ryssen et al., 1989; Kim and Mahan, 2001; Lawler et al, 2004). The Se speciation for Se-SMC used in the present study was not determined, however, a high portion of organic Se in Se-SMC as described previous study (Lee, 2004) could significantly increase Se deposition in the skeletal muscle of Hanwoo beef steers. Se concentration of the muscle in the dietary Se level $(0.6 \mathrm{ppm})$ from our result was similar to data of Hintze et al (2002) with the same level (approximately $0.6 \mathrm{ppm}$ ) in the diet.

On the other hand, Se concentration in the liver remarkably increased with supplementing Se-SMC. These results were similar to the data provided by Combs and Combs (1986), which reported that Se concentration in the liver was around four times higher than that in the skeletal muscle. Our data also indicated that Se concentration in the liver was up to maximally four folds increased compared with normal SMC alone. The increasing concentration in the liver by dietary Se level revealed the same pattern as skeletal muscle. High Se concentration in the liver compared with muscle is provided the fact 
that liver acts as a major pool of Se in the body.

In contrast, Se increment in the muscle by feeding Se-SMC was relatively low as minimally $35 \%$ to maximally $68 \%$ compared with Se-SMC unsupplemented group. Hintze et al. (2002) showed the similar results to ours, suggesting the limitation of Se accumulation in the muscle of beef steers. They further indicated that the transfer of dietary Se to muscle was inefficient as maximum of $2.6 \%$. However, Lawler et al. (2004) reported that when high-Se hay or wheat diet with supranutritional level of Se was fed to beef steers, Se concentration in the muscle showed tremendously increased value compared with the control or sodium selenate groups, suggesting that dietary level and chemical form of Se are crucial factors to produce high Se beef.

Our data showed that incorporation of SeSMC into the diet could be easy and inexpensive way to increase Se concentration in the body of beef steers. Furthermore, based on the health benefits of Se, we would expect that increased concentrations of Se in beef could contribute to human health by providing more Se.

\section{IMPLICATIONS}

Se-SMC supplementation to finishing Hanwoo steers did not affect performances and carcass characteristics. However, together with increased blood Se concentration and plasma GSH-Px activity, Se contents in tissues linearly increased as dietary Se increased. Therefore, our results, clearly, showed that Se in the SMC was highly bioavailable for intestinal absorption and increasing GSH-Px activity, and accumulation in tissues. Consequently, our results suggested that Se-SMC can be effectively utilized not only as an inexpensive way of supplementing Se for ruminants but also as another way of producing Se-fortified beef.

\section{ABSTRACT}

This study was conducted to determine effects of spent composts of Se-enriched mushrooms (Se-SMC) as the dietary selenium source on carcass characteristics, plasma glutathione peroxidase (GSH-Px) activity and Se deposition in finishing Hanwoo steers. In combination with both Se-SMC and normal SMC, experimental treatment diets were formulated to contain 0.1 , 0.3, 0.6 and $0.9 \mathrm{ppm}$ of Se on a dry matter basis. A total of 20 finishing Hanwoo steers (average $\mathrm{BW}=613 \mathrm{~kg}$, average age $=20$ to 24 mo) were allotted to treatments in four groups of five steers per pen for 12 wk preceding slaughter. While the experiment is employed, blood samples were taken to analyze Se concentration and GSH-Px activity, and muscle and liver samples were collected for analyses of Se contents in their tissues after slaughter. DMI and BW gain were not affected by dietary Se level and any toxic symptoms in treatments with a higher level of Se were not observed. No differences were noted for carcass characteristics. Se concentration in whole blood and plasma GSH-Px activity were linearly increased with the increasing level of dietary Se $(\mathrm{P}<0.01)$. Se content in the hind leg for Se-SMC supplemented groups significantly increased $(\mathrm{P}<0.05)$ upon dietary Se level, with $0.27,0.37,0.40$ and $0.46 \mu \mathrm{g} / \mathrm{g}$ dry, respectively. However, Se content in the loin was not affected by dietary Se levels. Se content in the liver was significantly increased $(\mathrm{P}<0.05)$ as dietary Se increased, with $0.79,1.40,2.39$ and $3.10 \mu \mathrm{g} / \mathrm{g}$ dry, respectively. These results suggested that Se in the Se-SMC was highly bioavailable, and Se-SMC might be used not only as an inexpensive way of providing Se for ruminants but also as another way of producing Se-fortified beef. 
(Key words: Selenium, SMC, Carcass characteristics, GSH-Px, Deposition, Hanwoo steers)

\section{ACKNOWLEDGMENT}

This trial was supported by MAF-ARPC (Grant No. 202115-03-2-SB010). The authors express appreciation for their aids.

\section{REFERENCES}

1. AOAC. 1995. Official Methods of Analysis. 16th ed. Association of Official Analytical Chemists, Washington, DC.

2. Clark, L. C., Combs, Jr., G. F, Turnbull, B. W., Slate, E. H., Chalker, D. K., Chow, J., Davis, L. S., Glover, R. A., Graham, G. F., Gross, E. G., Krongrad, A., Lesher, Jr. J. L., Park, H. K., Sanders, Jr. B. B., Smith, C. L. and Taylor, J. R. 1996. Effects of selenium supplementation for cancer prevention in patients with carcinoma of the skin. JAMA (J. Am. Med. Assoc.) 276:19571963.

3. Combs, G. F. and Combs, S. B. 1986. The role of selenium in Nutrition. Academic Press. Inc., New York, NY.

4. DeVore, V. R. and Greene, B. E. 1982. Glutathione peroxidase in post-rigor bovine semitendinosus muscle. J. Food Sci. 47:1406-1409.

5. Gunter, S. A., Beck, P. A. and Phillips, J. M. 2003. Effects of supplementary selenium source on the performance and blood measurements in beef cows and their calves. J. Anim. Sci. 81: 856-864.

6. Hintze, K. J., Lardy, G. P., Marchello, M. J. and Finley, J. W. 2001. Areas with high concentrations of selenium in the soil and forage produce beef with enhanced concentrations of selenium. J. Agric. Food Chem. 49:1062-1067.

7. Hintze, K.J., Lardy, G. P., Marchello, M. J. and Finley, J. W. 2002. Selenium accumulation in beef: Effect of dietary selenium and geographical area of animal origin. J. Agric. Food Chem. 50: 3938-3942.

8. Holben, D. H. and Smith, A. M. 1999. The diverse role of selenium within selenoproteins: a review. J. Am. Diet. Assoc. 99:836-843.

9. Kim, Y. Y. and Mahan, D. C. 2001. Comparative effects of high dietary levels of organic and inorganic selenium on selenium toxicity of growingfinishing pigs. J. Anim. Sci. 79:942-948.

10. Koenig, K. M., Rode, L. M., Cohen, R. D. H. and Buckley, W. T. 1997. Effects of diet and chemical form of selenium on selenium metabolism in sheep. J. Anim. Sci. 75:817-827.

11. Ku, P. K., Miller, E. R., Wahlstrom, R. C., Groce, A. W., Hitchcock, J. P. and Ullrey, D. E. 1973. Selenium supplementation of naturally high selenium diets for swine. J. Anim. Sci. 37:501505.

12. Lawler, T. L., Taylor, J. B., Finley, J. W. and Caton, J. S. 2004. Effect of supranutritional and organically bound selenium on performance, carcass characteristics, and selenium distribution in finishing beef steers. J. Anim. Sci. 82:1488-1493.

13. Lawrence, R. A. and Burk, R. F. 1976. Glutathione peroxidase activity in selenium-deficient rat liver. Biochem. Biophys. Res. Commun. 71:952958.

14. Lee, S. H. 2004. Studies on the production of the Se-enriched mushroom and determination of its selenium profile. In: Studies on the production of Se-fortified beef by supplementing spent composts of Se-enriched mushrooms in the finishing Hanwoo steer. Ph.D. dissertation, Konkuk Univ., Seoul, Korea.

15. McConnell, K. P. and Hoffman, J. L. 1972. Methionine-selenomethionine parallels in rat liver polypeptide chain synthesis. Fed. Proc. 31:691 (Abstr.).

16. Ministry of Agriculture \& Forestry (MAF) and National Livestock Research Institute (NLRI). 2002. Korean feeding standard for Korean cattle (Hanwoo), Korea.

17. Mahan, D. C., Cline, T. R. and Richert, B. 1999. Effects of dietary levels of selenium-enriched yeast and sodium selenite as selenium sources fed to growing-finishing pigs on performance, tissue selenium, serum glutathione peroxidase activity, carcass characteristics, and loin quality. J. Anim. Sci. 77:2172-2179. 
18. Mahan, D. C. and Parrett, N. A. 1996. Evaluating the efficacy of selenium-enriched yeast and sodium selenite on tissue selenium retention and serum glutathione peroxidase activity in grower and finisher swine. J. Anim. Sci. 74:2967-2974.

19. NRC. 1996. Nutrient requirements of beef cattle. 7th revised edition. National Academy Press, Washington, DC.

20. Ortman, K. and Pehrson, B. 1999. Effect of selenate as a feed supplement to dairy cows in comparison to selenite and selenium yeast. J. Anim. Sci. 77:3365-3370.

21. Peterson, P. J. and Spedding, D. J. 1963. The excretion by sheep of ${ }^{75}$ selenium incorporated into red clover (Trifolium pratense L.): The chemical nature of the excreted selenium and its uptake by three plant species. N. Z. J. Agric. Res. 6:13-23.

22. Puls, R. 1989. Mineral levels in animal health: Diagnostic data. Sherpa Int., Clearbrook, British Columbia, Canada.

23. Rayman, M. P. 2000. The importance of selenium to human health. The Lancet 356:233-241.

24. Rock, M. J., Kincaid, R. L. and Carstens, G. E. 2001. Effects of prenatal source and level of dietary selenium on passive immunity and thermometabolism of newborn lambs. Small Rumin. Res. 40:129-138.

25. Rotruck, J. T., Pope, A. L., Ganther, H. E., Hafeman, D. G., Swanson, A. B. and Hoekstra, W. G. 1973. Selenium: Biochemical role as a component of glutathione peroxidase. Science 179: 588-590.

26. SAS. 2000. SAS/STAT ${ }^{\circledR}$ User’s guide (Release 8.1 ed.). Statistics, SAS Inst, Inc., Cary, NC.

27. Smith, K. L., Hogan, J. S. and Conrad, H. R. 1988. Selenium in dairy cattle: Its role in disease resistance. Vet. Med. 83:72-78.

28. Steel, R. G. D. and Torrie, J. H. 1980. Principles and procedures of statistics: A biometrical approach (2nd Ed.). McGraw-Hill Book Co., New York.

29. Stefánka, Z., Ipolyi, I., Dernovics, M. and Fodor, P. 2001. Comparison of sample preparation methods based on proteolytic enzymatic processes for Se-speciation of edible mushroom(Agaricus bisporus) samples. Talanta 55:437-447.

30. Stevens, J. B., Olson, W. G., Kraemer, R. and Archambeau, J. 1985. Serum selenium concentrations and glutathione peroxidase activity in cattle grazing forages of various selenium concentrations. Am. J. Vet. Res. 46:1556-1560.

31. Stijve, T. 1977. Selenium content of mushrooms. Z. Lebensm. Unters. Forsch. 164(3):201-203.

32. Surai, P. F. 2000. Organic selenium and the egg: Lessons from Nature. Feed Compounder 20:16.

33. Tapiero, H., Townsend, D. M. and Tew, K. D. 2003. The antioxidant role of selenium and seleno-compounds. Biomed. Pharmacother. 57:134144.

34. Van Elteren, J. T., Woroniecka, U. D. and Kroon, K. J. 1998. Accumulation and distribution of selenium and cesium in the cultivated mushroom agaricus bisporus - A radiotracer - aided study. Chemosphere 36(8):1787-1798.

35. Van Ryssen, J. B. J., Deagen, J. T., Beilstein, M. A. and Whanger, P. D. 1989. Comparative metabolism of organic and inorganic selenium by sheep. J. Agric. Food Chem. 37:1358-1363.

36. Van Soest, P. J., Robertson, J. B. and Lewis, B. A. 1991. Methods for dietary fiber, neutral detergent fiber, and non-starch polysaccharides in relation to animal nutrition. J. Dairy Sci. 74:35833597.

37. Wright, P. L. and Bell, M. C. 1966. Comparative metabolism of selenium and tellurium in sheep and swine. Am. J. Physiol. 211:6-10.

(접수일자 : 2004. 8. 5. / 채택일자 : 2004. 10. 20.) 